\title{
Hydrogeological properties of hyper-saline geothermal brine and application of inhibiting siliceous scale via $\mathrm{pH}$ modification
}

\author{
Alper Baba ${ }^{\mathrm{a}, *}$, Mustafa M. Demir ${ }^{\mathrm{b}}$, Gonca A. Koç ${ }^{c}$, Celal Tuğcu ${ }^{\mathrm{c}}$ \\ a Izmir Institute of Technology, Geothermal Energy Research and Application Center, 35430 Gülbahçe, Urla, İzmir, Turkey \\ ${ }^{\mathrm{b}}$ Izmir Institute of Technology, Department of Materials Science and Engineering, 35430 Gülbahçe, Urla, Izmir, Turkey \\ ${ }^{\text {c }}$ ENDA Energy 35220, Izmir, Turkey
}

\section{A R T I C L E I N F O}

\section{Article history:}

Received 5 June 2014

Accepted 9 August 2014

\section{Keywords:}

Brine

$\mathrm{CO}_{2}$

Geothermal fluid

$\mathrm{pH}$

Scaling

Silicate

Tuzla

\begin{abstract}
A B S T R A C T
Scaling is a major obstacle in harnessing of geothermal energy from the geothermal resources. This paper presents a case study for inhibition of metal silicate scaling using formic acid, harvesting more energy in particular case of Tuzla Geothermal Field (TGF), located on Biga Peninsula, in the northwestern of Turkey. TGF is $5 \mathrm{~km}$ far from Aegean Sea and $80 \mathrm{~km}$ south of Çanakkale. Geothermal fluid of TGF has high salinity $\left(\mathrm{EC}>91 \mathrm{mS} / \mathrm{cm}\right.$ ) and medium temperature (reservoir temperature is $173^{\circ} \mathrm{C}$ ). The acidification of highsalinity brine to mitigate silicate scaling is examined. Results of the study showed that a compromise between scaling and corrosion is achieved by reducing $\mathrm{pH}$ of brine to $<6$ using $55 \mathrm{ppm}$ formic acid.
\end{abstract}

(c) 2014 Elsevier Ltd. All rights reserved.

\section{Introduction}

Geothermal is a renewable and sustainable source of energy. Geothermal fluids have been used for bathing, balneotherapy, washing dishes and clothes since prehistoric times in Turkey. There are a total of about 1500 thermal and mineral water spring groups in Turkey (MTA, 1980; Simsek et al., 2002). The country's installed heat capacity is $2705 \mathrm{MWt}$ for direct use and 243.35 MWe for power production (Dogan et al., 2014). In parallel to developing geothermal energy applications in Turkey, many sites experience detrimental scaling problems. Utilization of geothermal depends on thermodynamic characteristics and chemistry of fluid. These factors are determined by the geothermal system from which the fluid originates (Dogan et al., 2014; Mburu, 2009). Geothermal fluids are classified differently based on fluid temperature (Muffler and Cataldi, 1978; Hochstein, 1990; Benderitter and Cormy, 1990; Nicholson, 1993; Axelsson and Gunnlaugsson, 2000; Dickson and Fanelli, 2004). Intermediate and high enthalpy fluids have been used for power production. The reduction of temperature and pressure during production lowers the solubility and causes prodigious precipitation known as scaling (Gunnlaugsson, 1989;

\footnotetext{
* Corresponding author at: Izmir Institute of Technology, Geothermal Energy Research and Application Center, 35430 Gülbahçe, Urla, İzmir, Turkey. Tel.: +90 2327506807; fax: +90 2327506801 .

E-mail addresses: alperbaba@iyte.edu.tr, alperbaba33@yahoo.com (A. Baba).
}

Kristmannsdóttir, 1989; Honegger et al., 1989; Patzay et al., 2003; Demir et al., 2014).

Turkey, one of the most seismically active regions in the world, has a considerably high level of geothermal energy potential due to its geological and tectonic setting. Tuzla Geothermal Field, which is located $5 \mathrm{~km}$ from Aegean Sea and $80 \mathrm{~km}$ from south of Çanakkale, is on Biga Peninsula, in the northwestern Turkey (Fig. 1). Tuzla Village is the only settlement in study area, located near Ayvacık (Çanakkale). The village is located nearly $300 \mathrm{~m}$ east of the geothermal power plant, which has an installed power of $7.5 \mathrm{MWe}$ and annual energy production capacity of 51 GWh (ENDA, 2012).

Deposition of silicate scaling is the main handicap in many geothermal plants as well as in Tuzla geothermal systems. This problem reduces the efficiency of the geothermal power plant and causes economical loss. Scaling caused by geothermal fluid was discovered immediately after the start of operation. The type scaling is special and has not been encountered at other geothermal systems in Turkey. The scales observed in Tuzla geothermal system were examined in detail by Demir et al. (2014). PbS (Galena) and $\mathrm{CaCO}_{3}$ (aragonite or calcite) were detected in the down-hole and the surface pipeline. In contrast, the latter was heterogeneous in nature and consisted of mainly saponite like amorphous structure along with submicrometer-sized amorphous silica particles, layered double magnesium and iron hydroxide, and $\mathrm{NaCl}$ (Demir et al., 2014). That is why many studies have been going on to minimize scaling problem in the Tuzla Geothermal site. Considering the extent of scaling and loss in production at the early stages of 


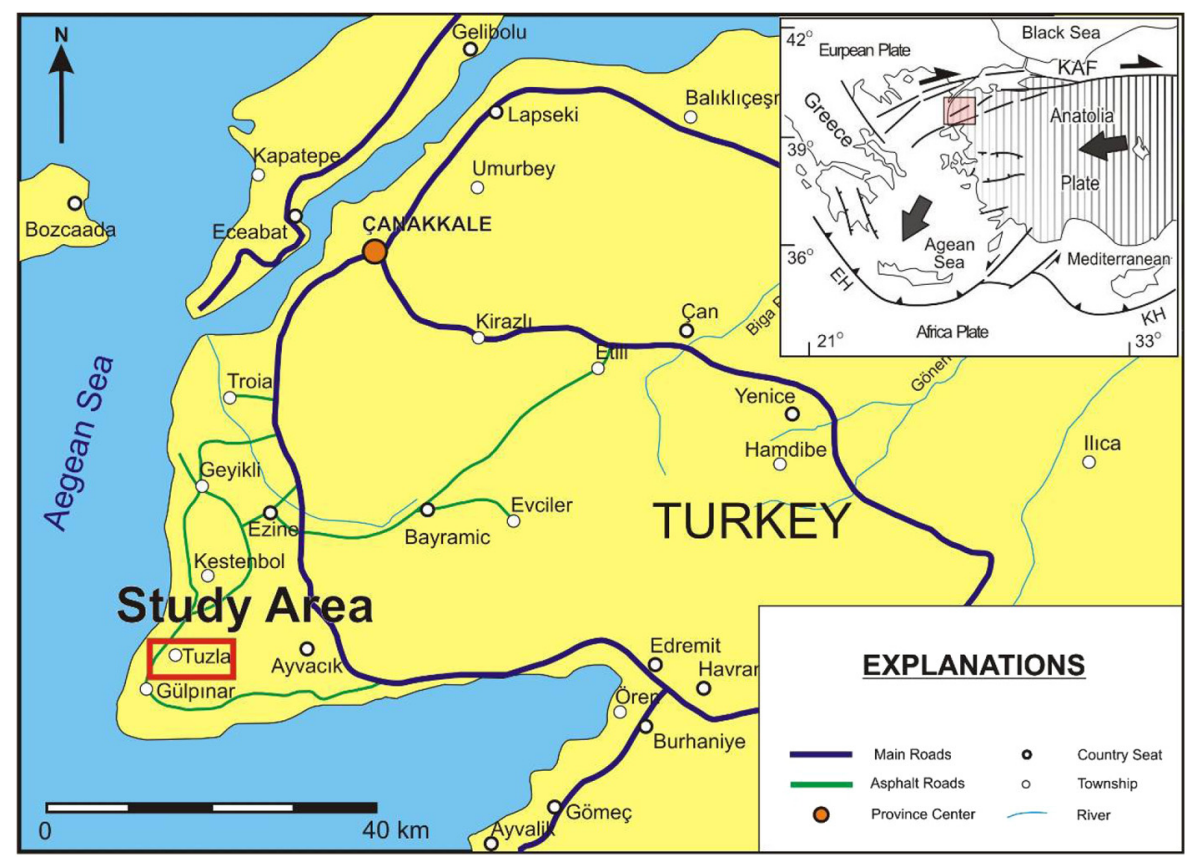

Fig. 1. Location map of Tuzla geothermal field (Demir et al., 2014).

operation, chemical trials that continued in 2011 have yielded favorable results, which have significantly, reduced the level of scaling.

Scale inhibition/control has been attempted using inhibitors (Gallup, 1998). Commercial organic scale inhibitors have been studied in Tuzla Geothermal power plant and none of them cause significant reduction in scale formation. Consequently, $\mathrm{pH}$ modification system has been adopted as a main pathway for scale prevention. Adjustment of brine $\mathrm{pH}$ has been found to be the most efficient method (Gallup, 1993). Currently, a number of fields such as Salton Sea (USA) have been using $\mathrm{pH}$ modification technology to control scale deposition. However, the optimization of dosage and the placement of acid injection are the two significant parameters that can vary from one field to another field. In this work, current solution of Tuzla geothermal power plant including dosage and the placement of dosage to minimize silicate scaling is mentioned. Formic acid was chosen as an environmentally friendly organic acid, which is also the simplest organic acid with similar chemical structure of $\mathrm{CO}_{2}$. Note that the removal $\mathrm{CO}_{2}$ was the main reason of increasing of $\mathrm{pH}$ and eventually causing silicate scaling. The organic acid has dual functions: (i) inhibition of colloidal silica formation (ii) dissolution of already formed deposits. The application of organic acid to the geothermal system seems promising as long as the potential corrosion can be carefully controlled.

\section{Methods}

Geothermal fluids were taken from wells in TGF (see Fig. 2). For major ions and for trace metal analyses, 1-L plastic bottles were used. To prevent the complex formation of trace elements with oxygen, samples were filtered by $0.45-\mu \mathrm{m}$ filter paper and acidified to $\mathrm{pH} \leq 2$ condition by adding $0.5 \mathrm{~N} \mathrm{HNO}_{3}$. The trace metal analyses were measured by ICP-AES. Electrical Conductivity (EC), temperature $\left({ }^{\circ} \mathrm{C}\right)$ and $\mathrm{pH}$ values were measured in situ with a multiparameter instrument. Chemical analyses were carried out using the ICP-AES for $\mathrm{Na}, \mathrm{K}, \mathrm{Ca}$, and $\mathrm{Mg}$ while $\mathrm{Cl}$ and $\mathrm{HCO}_{3}$ values were determined by titration method. In addition to water samples for periodic physical ( $\mathrm{pH}$ and $\mathrm{EC}$ ) and chemical analysis (total hardness,
$\mathrm{Si}, \mathrm{Fe}$ ) was taken from four different places (wellheads, after separator, before and after vaporizer) of the geothermal power plant system (Fig. 3). These analyses were done at the laboratories of Tuzla Geothermal Energy CO.

\section{Results and discussion}

\subsection{Geological and hydrogeological properties of Tuzla geothermal field}

Tuzla geothermal field (TGF) is located on an active fault zone. TGF is one of the most important geothermal fields in northwest of Turkey which is located between the African and Eurasian plates, within the Mediterranean Earthquake Belt where marked by young volcanics and active faults. The border of these plates allows circulation of water, heat flow and geothermal energy (Bozkurt, 2001; Baba and Sözbilir, 2012; Satman, 2013). Hot springs in Turkey are located generally nearby the fault systems, young volcanism, and hydrothermally altered areas (Simsek, 2003). Many studies have been conducted on TGF by researchers. Geothermal studies of Tuzla field started in 1966. Şamilgil (1966), Erdogan (1966), Ürgun (1971), Öngür (1973) and Alpan (1975) studied geological and volcanic features of Tuzla. Geophysical investigations were performed by Demirörer (1971) and Ekingen (1972). According to geological and geophysical surveys 10 thermal gradient wells were drilled from 50 to $100 \mathrm{~m}$ depth in 1974. Some of these wells' temperatures reached to $145^{\circ} \mathrm{C}$ at $50 \mathrm{~m}$ depth because dynamic boiling within some was lost in blow-outs (Karamanderesi and Öngür, 1974). Two deep exploration wells (between 814 and $1020 \mathrm{~m}$ depth range) were drilled in 1982 and 1983 by MTA. The reservoir depth was estimated between 333 and $553 \mathrm{~m}$ in volcanic rock at $173^{\circ} \mathrm{C}$, a production rate of $130 \mathrm{t} / \mathrm{h}$ and steam content of $13 \%$. The general characteristics of hydrothermal alteration were described by Gevrek and Sener (Gevrek and Sener, 1985), and they stated that geothermal fluid can range from 150 to $225^{\circ} \mathrm{C}$ temperature (Şener and Gevrek, 2000). Similarly, Mutlu and Gülec (1998) calculated the reservoir temperature of Tuzla to be between $187^{\circ} \mathrm{C}$ and $212^{\circ} \mathrm{C}$ by using different geothermometers. Baba and Deniz (2005) 


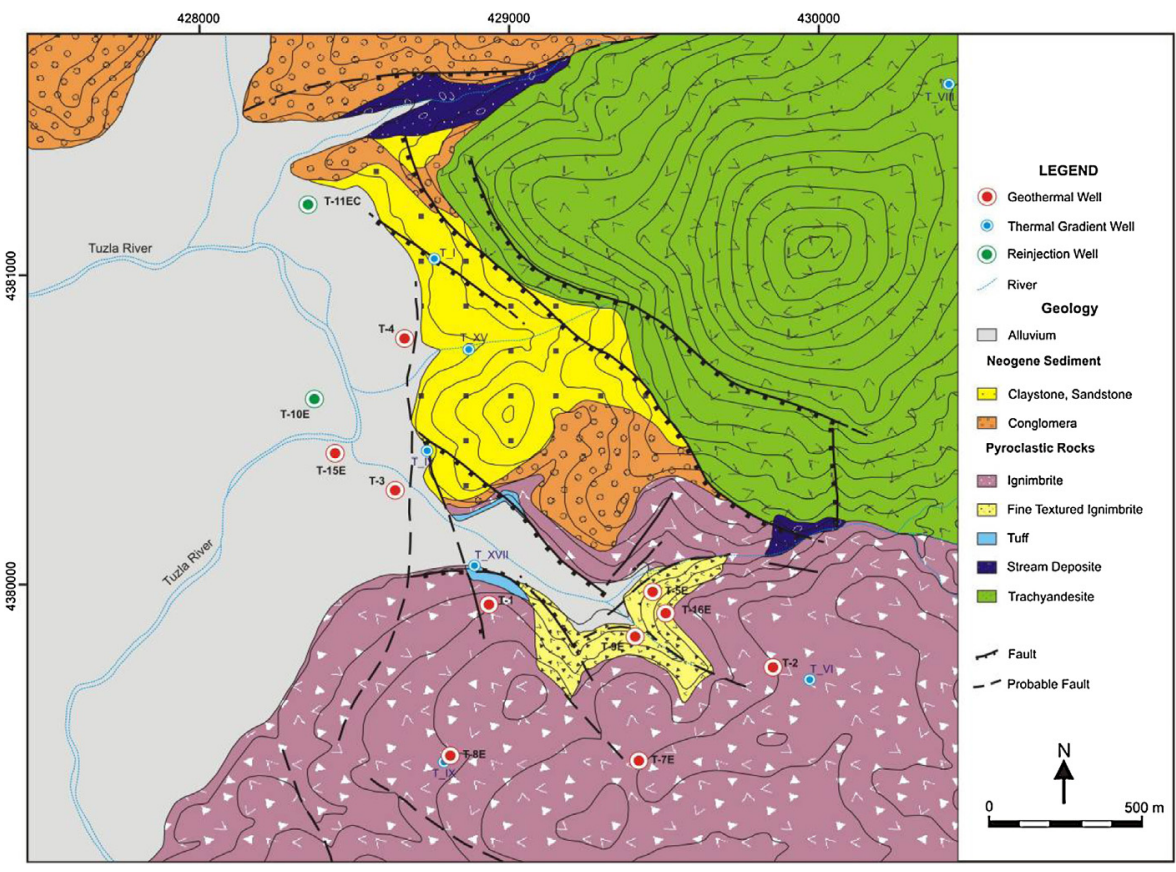

Fig. 2. Geology map of Tuzla geothermal site (modified from WES JEC, 2006; HU, 2008a,b).

estimated subsurface reservoir temperatures that ranged from $182^{\circ} \mathrm{C}$ to $232^{\circ} \mathrm{C}$. Tuzla Geothermal Energy CO was drilled eight wells. This company built one of geothermal power generation in 2009 in this region.

TGF is hosted by rhyolite lavas and pyro-clastic deposits. Base zone consists of calcschiste, quartzite and marble, which are metamorphic rocks that include quartz, orthoclase, albite and mica minerals. The Granodiorite intrusion consists of quartz, orthoclase, albite and biotite, intruded the metamorphic basement. The metamorphic rocks and granodiorite intrusion are covered by andesitic volcanic rocks; trachyandesite, trachyte and rhyodacitic ignimbrite. These rocks, especially trachyandesite, include quartz, calcite minerals that are highly altered and covered by sediments and alluvium (Demir et al., 2014; Baba et al., 2008, 2009). The currently active thermal regime in Tuzla is associated with volcanism. Generally, the major geologic structures are recognized to be N-S and NW-SE trending fault systems (see Fig. 2). Along the N-S trending fault system, many geothermal springs are developed. The major faults trending NW-SE along the western and southern slope of the Tuzla Hill are normal faults (Demir et al., 2014).

Volcanic rocks are reservoir of the geothermal fluid. Neogene sandstone and claystone is a cap rock of the system. The origin of the thermal springs in Tuzla geothermal field was investigated by Mützenberg (1997), Balderer (1997) and Vengosh et al. (2002).
$\mathrm{Na}-\mathrm{Cl}$ water composition indicates a marine origin and also waterrock interactions. According to Balderer (1997) and Mützenberg (1997), geothermal fluid of Tuzla is fossil saline water that has been stuck between Miocene sediments. Besides, Vengosh et al. (2002) have predicted that Tuzla geothermal water is formed by dissolution of marine evaporations. The water from the wells is acidic due to an excess of free $\mathrm{CO}_{2}$, which is the result of the high partial pressure of this gas in the well. The temperatures of geothermal fluid in wells range from 46 to $173^{\circ} \mathrm{C}$. The highest temperature in production well T9E and T16E are $149.1^{\circ} \mathrm{C}$ and $150.6^{\circ} \mathrm{C}$, respectively in Tuzla geothermal site. The wellhead pressure ranges from 3.61 to 3.74 bar in production wells (Demir et al., 2014). Hydrogeochemical results show that Tuzla geothermal fluids have high $\mathrm{Na}$ and $\mathrm{Cl}$ content and parallel lines. All samples have the same reservoir and $\mathrm{Na}^{+}-\mathrm{Cl}^{-}$water composition indicates a marine origin. These type saline geothermal waters classify as "Brine". According to the Piper and Schoeller diagrams in Figs. 4 and 5, the geothermal brine is in $\mathrm{NaCl}$ facies. Waters sampled from the geothermal wells are generally enriched in $\mathrm{Na}^{+}$and $\mathrm{Cl}^{-}$and these major anion and cation have linear correlation (Fig. 6). Of the all defined geothermal fluid in TGF appear to have equilibrated with the reservoir rocks as indicated by their positions on a Giggenbach plot (Fig. 7). The geothermal fluids from the field plot in a linear array with a full equilibration temperature of $160-220^{\circ} \mathrm{C}$.

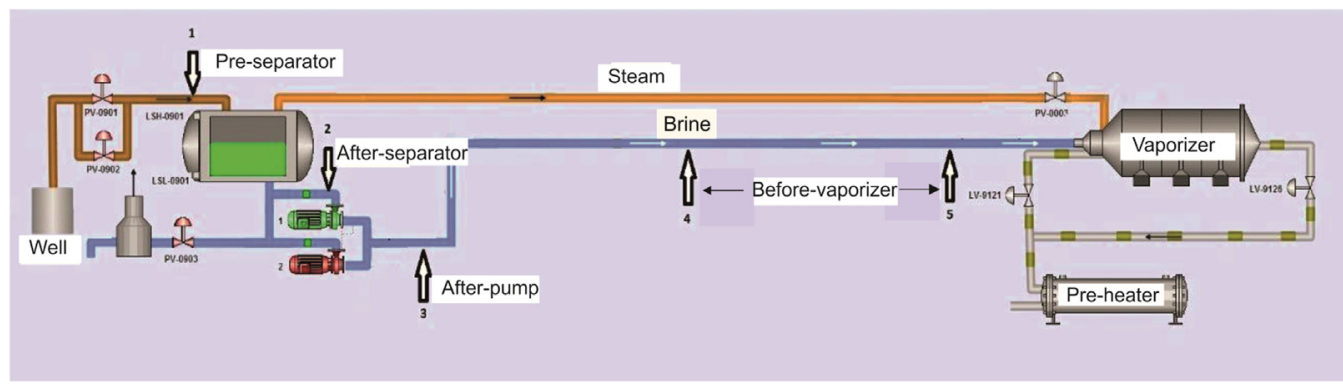

Fig. 3. Sample location in geothermal system. 
Tuzla Geothermal Field (Piper Plot)

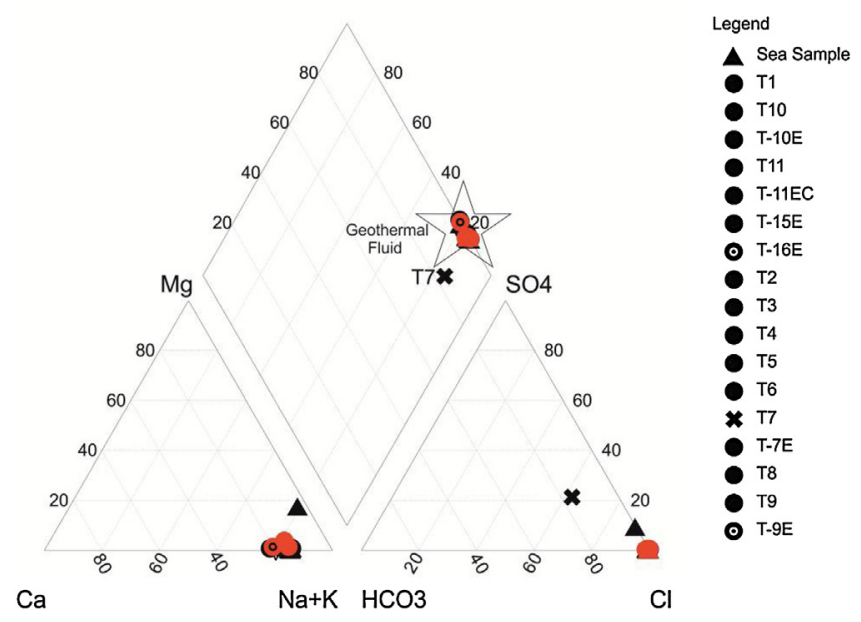

Fig. 4. Piper diagram of geothermal fluid.

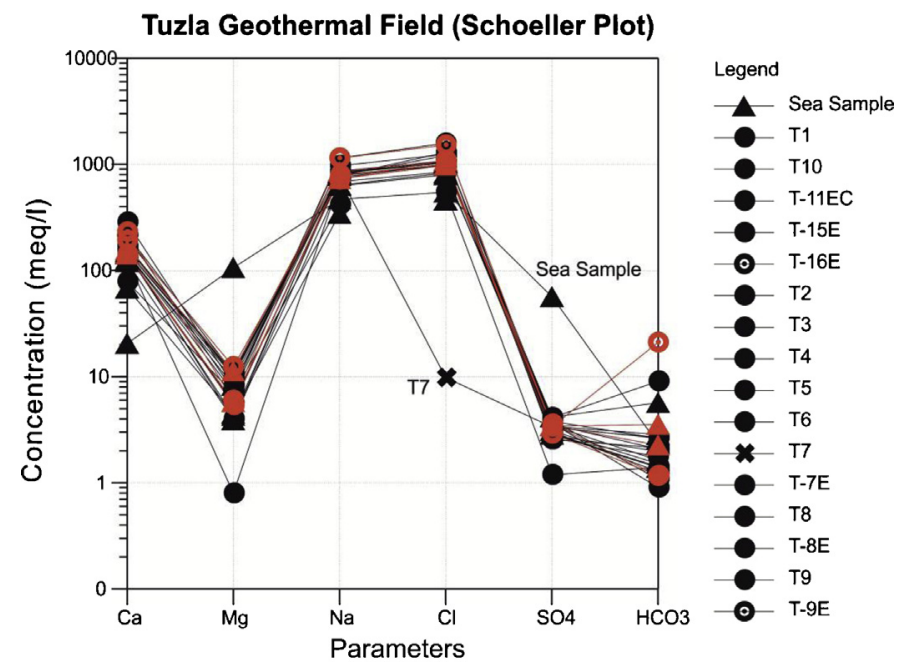

Fig. 5. Schoeller diagram of geothermal fluid.

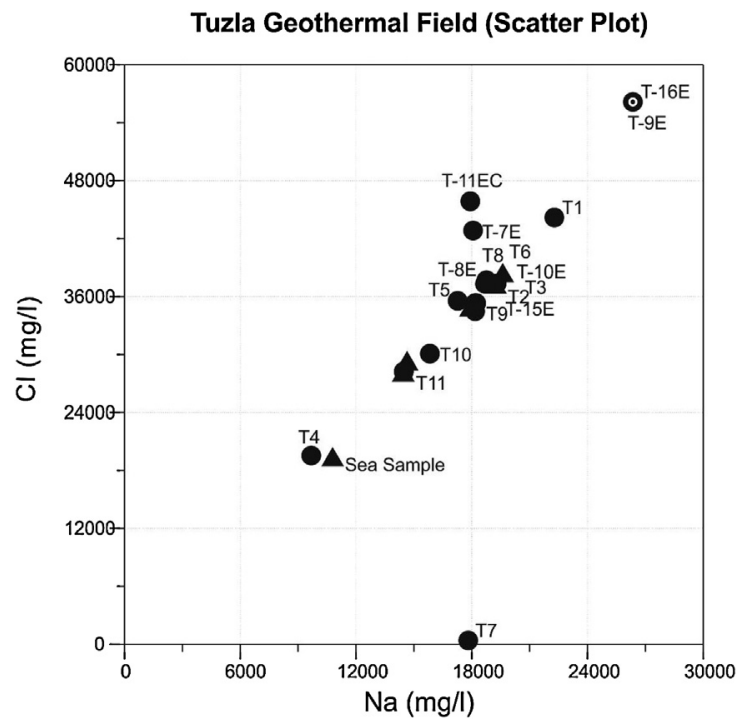

Fig. 6. Scatter diagram of geothermal fluid.
Tuzla Geothermal Fluid (Giggenbach Triangle)

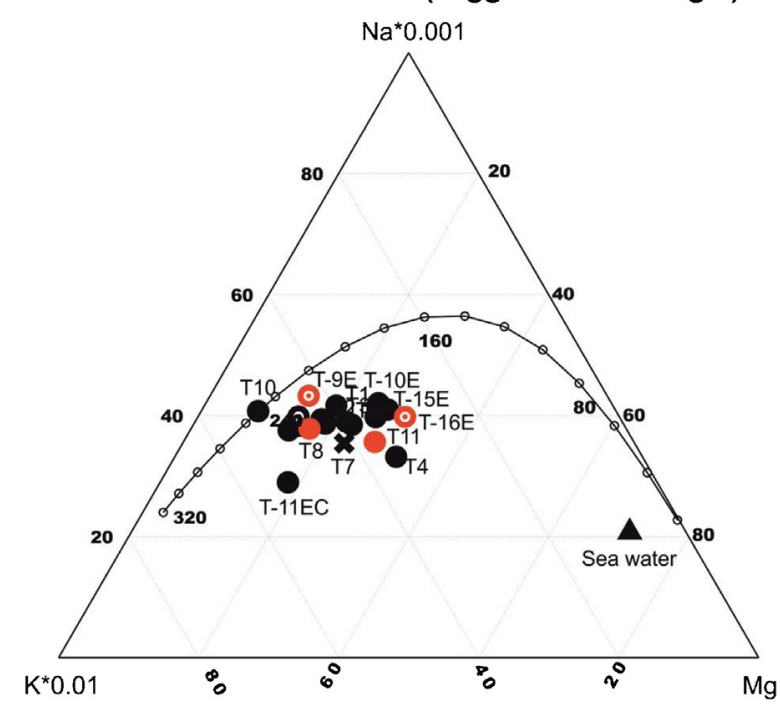

Fig. 7. Giggenbach diagram of geothermal fluid.

\subsection{Scale formation}

The reservoir of TGF is mainly composed of quartz and/or other forms of silica. Dissolution of quartz results in the formation of silicic acid, $\mathrm{Si}(\mathrm{OH})_{4}$. When silicic acid saturates, the silanol groups undergo condensation (Eq. (1)).

$\mathrm{Si}(\mathrm{OH})_{4} \rightarrow(\mathrm{HO})_{3} \mathrm{SiOSi}(\mathrm{OH})_{3}+\mathrm{H}_{2} \mathrm{O}$

$\mathrm{OFeOH} \cdot \mathrm{H}_{2} \mathrm{O}+2 \mathrm{Si}(\mathrm{OH})_{4} \rightarrow \mathrm{OFeOSi}(\mathrm{OH})_{3}+2 \mathrm{H}_{2} \mathrm{O}$

This reaction is the first stage of silica polymerization. The cascade condensation continues in three dimensions to form trimers, tetramers, oligomers, and eventually polymeric form of silica. The ones which are smaller than the critical size are thermodynamically unstable and easily dissolved under shear flow of brine. When a critical mass regarding silica polymerization is achieved, the nuclei precipitate, which are indeed discrete silica particles. The removal of $\mathrm{CO}_{2}$ after flashing point increases $\mathrm{pH}$, i.e. the concentration of $\mathrm{OH}$ relatively increases. Metal hydroxides and oxohydroxides are water insoluble (Petrucci et al., 2007). In particular case of Tuzla, the brine is rich in terms of Fe and $\mathrm{Mg}$ cations. The scale may be formed by the reaction of hydrates ferric oxhydroxide with silicic acid or silicic acid oligomers according to Eq. (2). The association of the particles is connected over long ranges. The mechanism described above refers to homogeneous nucleation. The nucleation process taking place on a surface is called heterogeneous nucleation, which requires less energy compared to homogeneous one. This is the case in fact, for scale formation on the inner/outer surface of pipes. Fig. 8 shows cartoon demonstration of the scale formation in the inner surface of the pipes. Initially, the inner surface is free of scale particularly after cleaning. The nucleation of colloidal silica takes place in brine. The colloids adsorb to the inner surface of the pipes. The nuclei undergoes ripening and growth under shear flow. Due to the high temperature and extension of the time, the deposits age and get denser structure. Simultaneously, newly formed layers may accumulate on the surface of the dense silicate. This new layer of deposit might be soft and porous in nature. Under continuous heat and aging, the deposit eventually gets denser and thicker. As a result, the diameter of the pipe is gradually reduced. 


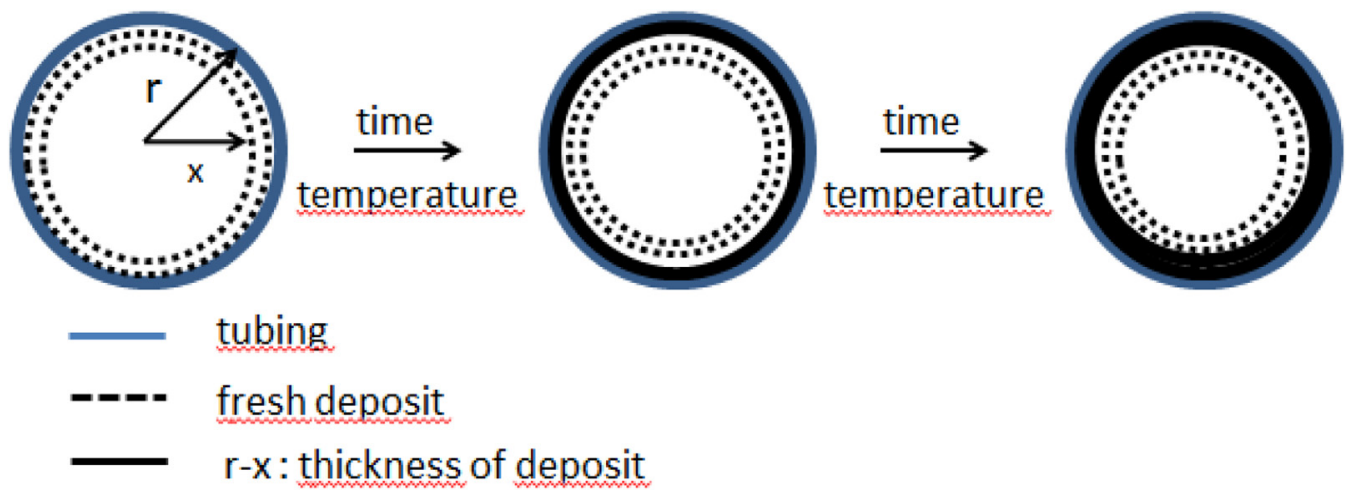

Fig. 8. Model of the formation of metal silicate scale at the inner surface of tubings upon aging in the system.

\section{3. pH modification}

Tuzla geothermal fluid contains high concentration of dissolved silica which leads to formation of amorphous silica scale in the equipment and surface pipelines. Solubility of silicic acid at various $\mathrm{pH}$ is an established phenomenon. The solubility is a parabolic function showing a minimum nearly at $\mathrm{pH}=7.0$ (Ketsetzi et al., 2008). There seems two ways to increase solubility by $\mathrm{pH}$ modification, either decrease or increase $\mathrm{pH}$. Increasing $\mathrm{pH}$ with caustic seems a way to increase solubility and therefore minimize the deposition. However, high $\mathrm{pH}$ has a risk of formation of metal hydroxides and oxohydroxides, which may cause the formation of some other source of deposits. Therefore, scaling control by increasing $\mathrm{pH}$ does not seem plausible. Rather, lowering $\mathrm{pH}$ of brine appears to be the wise approach for kinetic inhibition of the formation of deposit.

Generally speaking, undesirable deposit formation can be prevented by many ways such as using commercial inhibitors. However, the inhibitors has no or limited influence on the scale formation. The most effective method for the retardation of scaling is reducing $\mathrm{pH}$ of the brine. It must be noted that there is a tradeoff between scale prevention and corrosion under acidic condition. The key point is to find the correct acid and acid concentration for $\mathrm{pH}$ modification. Formic acid is a good choice due to low cost, ease of handling, and safety compared to inorganic acids such as $\mathrm{HCl}$ and $\mathrm{H}_{2} \mathrm{SO}_{4}$. The inorganic acids may also cause formation of secondary scaling for instance anhydrites; however, the dosing formic acid does not cause such complications (Yu and Savage, 1998). Moreover, formic acid is capable of reducing ferric into ferrous ions to inhibit the formation of the deposits by forming brine-soluble divalent iron. This redox reaction taking place between formic acid and ferric may play the active role in mitigation of the iron silicate.

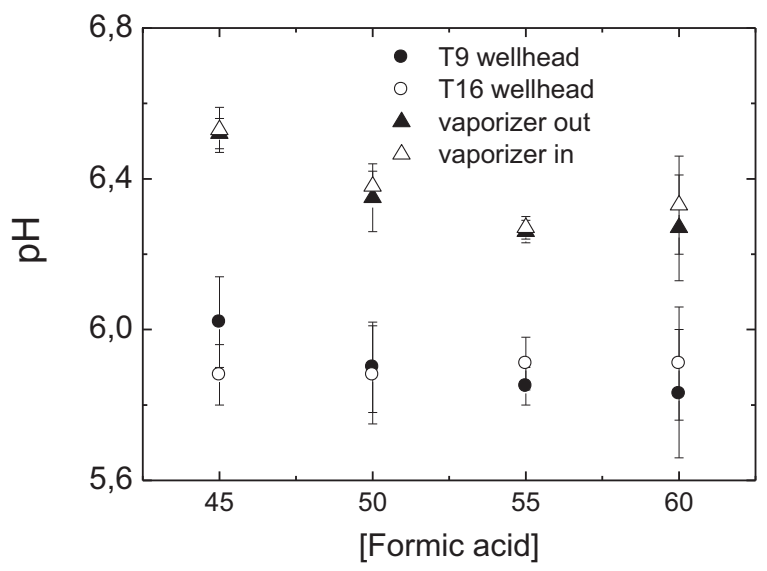

Fig. 9. pH and ion concentration at different formic acid concentrations.

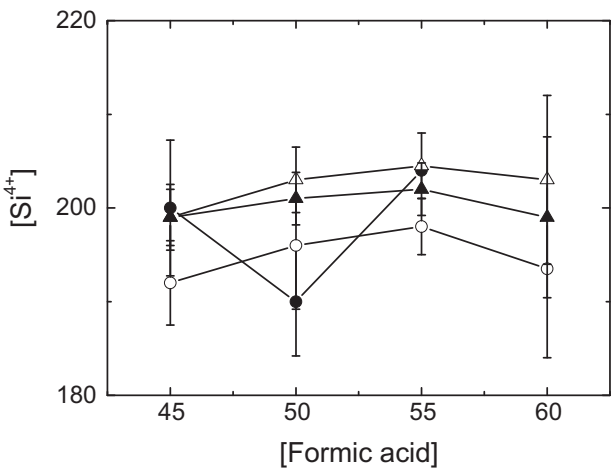

Fig. 10. Si and ion concentration at different formic acid concentrations.

To determine which dosage remains effective for reducing ferric cations in brines having a $\mathrm{pH}$ below 6.0, a series of concentrations was conducted in the system. The brines were analyzed for the concentration of iron ions before and after treatment of formic acid. Sampling has been carried out at different regions of the system: (i) T9 wellhead, (ii) T16 wellhead, (iii) vaporizer in and (iv) vaporizer out. The results of analysis were treated statistically and presented in Fig. 9. Panel a shows pH of brine as a function of formic acid concentration. Not surprisingly, $\mathrm{pH}$ of brine decreases as the applied acid concentration increases (Fig. 9). Further reducing of $\mathrm{pH}$ inevitably causes corrosive detrimental effects. As a result of decrease in $\mathrm{pH}$, partial dissolution of deposit takes place and concentration of ions such as $\mathrm{Si}^{4+}$ (Fig. 10), total iron (Fig. 11), and total hardness (Fig. 12) increases slightly. It is known that $\mathrm{CO}_{2}$ is soluble in water. The solubility of carbonate minerals is strongly influenced

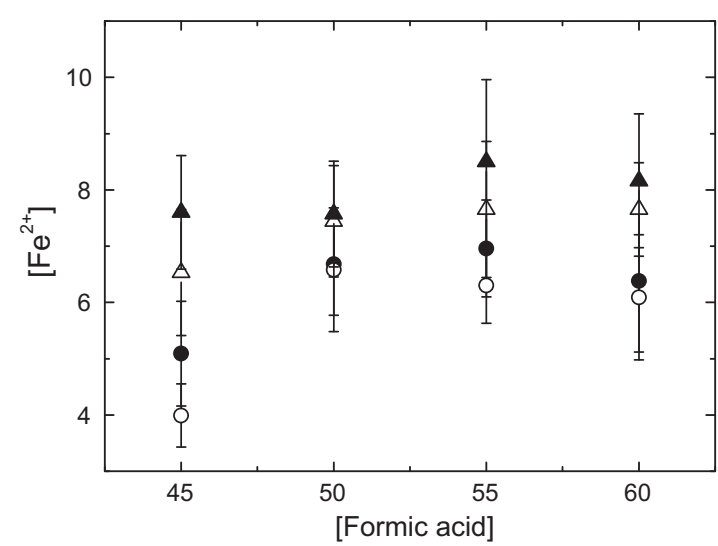

Fig. 11. Fe and ion concentration at different formic acid concentrations. 


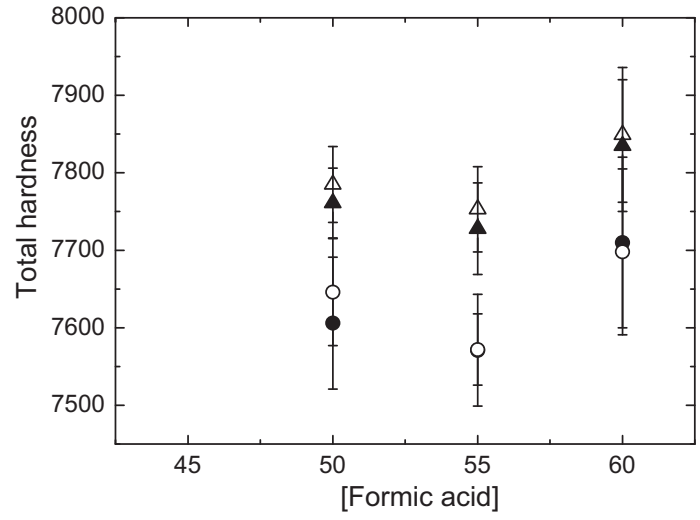

Fig. 12. Total hardness and ion concentration at different formic acid concentrations.

Table 1

Thickness of the deposits at different concentration of formic acid and scaling time.

\begin{tabular}{llll}
\hline Time range & Formic acid & Month & $\begin{array}{l}\text { Thickness of the } \\
\text { scale }(\mathrm{mm})\end{array}$ \\
\hline $20.11 .2012-20.02 .2013$ & 60 & 3 & $1.50-1.70$ \\
$20.02 .2013-20.08 .2013$ & $50-60$ & 6 & $1.52-3.68$ \\
$20.08 .2013-24.12 .2013$ & 55 & 4 & $1.90-2.20$ \\
\hline
\end{tabular}

by $\mathrm{pH}$ and the activity of carbon dioxide dissolved in geothermal waters (Arnorsson, 1989). $\mathrm{CO}_{2}$ comes out of solution as soon as it leaves wellhead. Therefore, wellhead has lower $\mathrm{pH}$ compared to vaporizer in/out.

The thickness of deposit at different acid concentrations hints about the efficiency of the $\mathrm{pH}$ modification. The thickness of the deposit at Vaporizer tubings was followed when the system is shut down for cleaning. Table 1 shows the results of this measurement. Half $\mathrm{mm}$ deposit on average is developed at the inner surface tubing per month. Based on these results, the system was optimized such that the dosage was applied to vaporizer at $55 \mathrm{ppm}$. At higher acid concentrations, the thickness of the deposit is very thin and the deposit is soft and powder like texture. Since the homogeneous thickness along the pipeline may not be provided, formic acid may attack at any region on the surface of pipes may induce pitting type degradation and eventually corrosion. This is because high acid concentration is not desirable although it is absolutely beneficial for the dissolution of deposits. Moreover, a thin layer of scaling is let on the inner surface of metal pipe to provide a protective layer against corrosion. For lower formic acid concentrations, inhibition of scaling does not take place effectively. Thus, the concentration of formic acid was optimized such that scaling is inhibited with the minimum level of formic acid. Based on a serial of trials in the geothermal system, the concentration of formic acid was adjusted to $55 \mathrm{ppm}$. It has been noted that the application of formic acid do

Table 2

Elemental composition of deposits obtained from the power plant.

\begin{tabular}{lcc}
\hline Elements & July 2013 & December 2013 \\
\hline $\mathrm{Fe}$ & 27.5 & 29.68 \\
$\mathrm{Si}$ & 17.7 & 16.86 \\
$\mathrm{Ca}$ & 2.0 & 2.27 \\
$\mathrm{Mg}$ & 5.3 & 4.30 \\
$\mathrm{Na}$ & 3.6 & 2.83 \\
$\mathrm{~Pb}$ & 0.4 & 0.73 \\
$\mathrm{Mn}$ & 1.1 & 1.15 \\
$\mathrm{Al}$ & 0.6 & 0.52 \\
$\mathrm{Ta}$ & 0.7 & 0.95 \\
$\mathrm{P}$ & 0.2 & 0.20 \\
$\mathrm{Zn}$ & 0.8 & 1.16 \\
\hline
\end{tabular}

not cause a remarkable and elemental and morphological change in silicate deposit. Table 2 presents elemental composition of deposits obtained from the Tuzla Geothermal Power Plant in July and December of 2013. The composition of the deposits seems almost identical. The structure of the both deposits show iron magnesium silicate with low crystallinity.

Formic acid prevents the formation of silica colloids as well as dissolves the already aged silicates. The concentrations of dissolved metals in geothermal brines varies from location to location so that the metal cations capable of precipitation at any given geothermal site may include silicate forming cations. Since the scaling is heavily seen in vaporizer and it is the most costly component in the system, acid dosage is applied just before vaporizer unit.

\section{Conclusions}

Deposition of silicate scaling is the main handicap in many geothermal plants such as Tuzla geothermal systems in Turkey. This problem reduces the efficiency of the geothermal power plant and causes economical loss. pH modification system has been adopted as a main pathway for scale prevention. $\mathrm{pH}$ modification process is studied in a model system at TGF to minimize amorphous silica and metal silicate deposition. The tests applied in the field showed that dosing formic acid from the entrance of vaporizer unit at $55 \mathrm{ppm}$ is the optimum condition for the minimization of scaling. Formic acid has been optimized to the system from the beginning of Vaporizer at $55 \mathrm{ppm}$. Thereby, the stand time is retarded from 1 to 6 months. This formalism can be applied other plants that has similar deposit structure and composition.

\section{References}

Alpan, S., 1975. Geothermal energy exploration in Turkey. In: 2nd United Nation Symposium on the Development and Use of Geothermal Resources, San Francisco, CA, USA, p. 25.

Arnorsson, S., 1989. Deposition of calcium carbonate minerals from geothermal waters $\sim$ theoretical considerations. Geothermics 18, 33-39.

Axelsson, G., Gunnlaugsson, E., 2000. Long-term Monitoring of High- and Low Enthalpy Fields Under Exploitation. International Geothermal Association. World Geothermal Congress 2000 Short Course, Kokonoe, Kyushu District, Japan, pp. 226.

Baba, A., Deniz, O., Ozcan, H., Erees, S.F., Cetiner, S.Z., 2008. Geochemical and radionuclide profile of Tuzla geothermal field, Turkey. Environ. Monit. Assess. 145 (1-3), 361-374.

Baba, A., Deniz, O., 2005. Determine of potential, application and environmental properties of geothermal resources in Biga Peninsulla. TUBiTAK Project, ÇAYDAG-104Y082.

Baba, A., Sözbilir, H., 2012. Source of arsenic based on geological and hydrogeochemical properties of geothermal systems in Western Turkey. Chem. Geol. 334, 364-377.

Baba, A., Yüce, G., Deniz, O., Uğurluoğlu, Y.D., 2009. Hydrochemical and isotopic composition of Tuzla Geothermal (Canakkale - Turkey) field and its environmental impacts. J. Environ. Fresenius 10, 144-161.

Balderer, W., 1997. Mechanisms and Processes of Groundwater Circulation in Tectonic Active Areas. In: Schindler, C., Pfister, M. (Eds.), Active Tectonics of Northwestern Anatolia - The Marmara Project Theme 5, Regional Contributions, 375-415. vdf Hochschulverlag, Zürich.

Benderitter, Y., Cormy, G., 1990. In: Dickson, M.H., Fanelli, M. (Eds.), Possible Approach to Geothermal Research and Relative Cost Estimate. Small Geothermal Resources. UNITARRJNDP Centre for Small Energy Resources, Rome, Italy, pp. 61-71

Bozkurt, E., 2001. Neotectonics of Turkey - a synthesis. Geodinam. Acta 14, 3-30.

Demir, M.M., Baba, A., Atilla, V., İnanlı, M., 2014. Types of the scaling in hyper saline geothermal system in Northwest Turkey. Geothermics 50, 1-9.

Demirörer, M., 1971. Resistivity survey of Tuzla-Kestanbol hot springs and surrounding. MTA report, Ankara (unpublished).

Dickson, M.H., Fanelli, M., 2004. What is Geothermal Energy? Istituto di Geoscienze e Georisorse. CNR, Pisa, Italy.

Dogan, I., Demir, M.M., Baba, A., 2014. In: Baba, A., Bundschuh, D., Chandrasekharam, D. (Eds.), Scaling Problem of the Geothermal System in Turkey. Geothermal Systems and Energy Resources, Turkey and Greece, pp. 225-234.

Ekingen, A., 1972. Gravimetric Survey of Ezine - Ayvacik - Bayramic Surrounding. MTA Report, no: 4859, Ankara.

ENDA, 2012. Annual Report. Enda Energy CO., Izmir, Turkey.

Erdogan, E., 1966. Geothermal energy possibility of survey and tectonic mapping of Tuzla hot springs and surrounding. MTA report, Ankara (unpublished). 
Gallup, D.L., 1993. The use of reducing agents for control of ferric silicate scale deposition. Geothermics 22, 39-48.

Gallup, D.L., 1998. Aluminum silicate scale formation and inhibition (2): scale solubility and laboratory and field inhibition tests. Geothermics 27, 483-501.

Gevrek, A.I., Sener, M., 1985. The determination of hydrothermal alteration zones by clay minerals in Canakkale - Tuzla area. In: 2nd Turkish National Clay Symposium, Hacettepe University, Ankara, Turkey.

Gunnlaugsson, E., 1989. Magnesium-silicate scaling in mixture of geothermal water and deaerated fresh water in a district heating system. Geothermics 18 (1-2), $113-120$.

Hochstein, M.P., 1990. Classification and assessment of geothermal resources. In: Dickson, M.H., Fanelli, M. (Eds.), Small geothermal resources. UNITAR/UNDP Centre for Small Energy Resources, Rome, Italy.

Honegger, J.L., Czernichowski-Lauriol, I., Criaud, A., Menjoz, A., Sainson, S., Guezennec, J., 1989. Detailed study of sulfide scaling at La Courneuue Nord, a geothermal exploitation of the Paris Basin, France. Geothermics 18 (1-2), 137-144.

$\mathrm{HU}, 2008 \mathrm{a}$. Evaluation report on geological, hydrological properties of T-7E ve T-8E research/production well in Tuzla (Canakkale) geothermal field. Ankara.

$\mathrm{HU}, 2008 \mathrm{~b}$. Evaluation report on geological, hydrological properties of T-10E production well in Tuzla (Çanakkale) geothermal field. Ankara.

Karamanderesi, I.H., Öngür, T., 1974. The Report of Gradient Wells Tuzla (Canakkale) Geothermal Field. MTA Report, no: 5524, Ankara.

Ketsetzi, A., Stathoulopolou, A., Demadis, K.D., 2008. Being green in chemical water treatment technologies: issues, challenges and developments. Desalination 223, 487-493.

Kristmannsdóttir, H., 1989. Types of scaling occurring by geothermal utilization in Iceland. Geothermics 18 (1-2), 183-190.

Mburu, M., 2009. Geothermal Energy Utilisation. Short course IV on exploration for geothermal resources, -GTP, KenGen and GDC, at Lake Naivasha, Kenya., pp. $1-22$.

MTA, 1980. Hot and Mineral Water Inventory. General Directorate of Mineral Research and Exploration (MTA), MTA Rap., Ankara.

Muffler, P., Cataldi, R., 1978. Methods for regional assessment of geothermal resources. Geothermics 7, 53-89.

Mutlu, H., Güleç, N., 1998. Hydrogeochemical outline of thermal waters and geothermometry applications in Anatolia (Turkey). J. Volcanol. Geotherm. Res. 85, 495-515.
Mützenberg, S., 1997. Nature and origin of the thermal springs in the Tuzla area, Western Anatolia, Turkey. In: Schindler, C., Pfister, M. (Eds.), Active Tectonic of Northwestern Anatolia - The Marmara Poly-Project. vdf hochschulverlag AG an der ETH, Zurich, pp. 301-317.

Nicholson, K., 1993. Geothermal Fluids, XVIII. Springer Verlag, Berlin, pp. 264.

Öngür, T., 1973. Volcanology and geological report of Canakkale Tuzla geothermal area. MTA report, Ankara (unpublished)

Patzay, G., Karman, H.F., Pota, G., 2003. Preliminary investigations of scaling and corrosion in high enthalpy geothermal wells in Hungary. Geothermics 32 627-638.

Petrucci, R.H., Herring, F.G., Madura, J.D., Bissonnette, C., 2007. General Chemistry: Principles and Modern Applications, 10th ed. Pearson Canada, Toronto, pp. 158.

Samilgil, E., 1966. Hydrogeological Report of Geothermal Energy Possibility Survey of Hot Springs of Kestanbol and Tuzla Village of Canakkale. MTA Report no: 4274 Ankara.

Satman, A., 2013. Geothermal energy in world and in Turkey. In: National Plant Engineering symposium, pp. 3-21 (in Turkish).

Şener, M., Gevrek, A., 2000. Distribution and significance of hydrothermal alteration minerals in the Tuzla hydrothermal system, Çanakkale, Turkey. J. Volcanol. Geotherm. Res. 96, 215-218.

Simsek, S., Yildirim, N., Simsek, Z.N., Karakus, H., 2002. Changes in geotherma resources at earthquake regions and their importance. In: Proceedings of Middle Anatolian Geothermal Energy and Environmental Symposium, pp. 1-13.

Simsek, S., 2003. Hydrogeological and isotopic survey of geothermal fields in the Buyuk Menderes Graben, Turkey. Geothermics 32, 669-678.

Ürgun, S., 1971. The Geology of Tuzla-Kestanbol (Canakkale) Surrounding and Geothermal Energy Possibility. MTA Report, no: 4664, Ankara.

Vengosh, A., Helvacı, C., Karamanderesi, İ.H., 2002. Geochemical constraints for origin of thermal waters from western Turkey. Appl. Geochem. 17, $163-183$.

WES JEC, 2006. Report on geothermal development survey in the Canakkale-Tuzla Field, Turkey. West Japan Engineering Consultants Inc.

Yu, J., Savage, P.E., 1998. Decomposition of formic acid under hydrothermal conditions. Ind. Eng. Chem. Res. 37 (1), 2-10. 